Egyptian Journal of Aquatic Biology \& Fisheries

Zoology Department, Faculty of Science,

Ain Shams University, Cairo, Egypt.

ISSN $1110-6131$

Vol. 25(2): 897 - 912 (2021)

www.ejabf.journals.ekb.eg

\title{
A Review on Medicinal Plants and Immune Status of Fish
}

\author{
Nipa Gupta ${ }^{1}$, Shikta Rani Kar ${ }^{2}$, Anindita Chakraborty ${ }^{2 *}$
}

1. Department of Aquaculture, Hajee Mohammad Danesh Science \& Technology University, Dinajpur-5200, Bangladesh

2. Department of Genetic Engineering \& Biotechnology, Shahjalal University of Science and Technology (SUST), Sylhet-3114, Bangladesh

*Corresponding Author: aninditamoury@yahoo.com

\section{ARTICLE INFO}

Article History:

Received: March 1, 2021

Accepted: April 14, 2021

Online: April 30, 2021

\section{Keywords:}

Medicinal plant,

Fish disease,

Health benefit,

Immune system,

Immune gene.

\section{ABSTRACT}

Nowadays, one of the limiting factors in aquaculture is infectious diseases which cause substantial economic losses worldwide. Antibiotics are mainly used to control these diseases even though they have several adverse effects on the environment and human life. In this context, researchers are trying to find an alternative to antibiotics, which should be eco-friendly and economically feasible for fish farmers. Medicinal plants can be used as an alternative to antibiotics, which have been showing promising possibilities in numerous fish health benefits including modulation of the fish immune system (one of the most commonly purported benefits). This review describes the immunomodulatory role of different medicinal plants to boost the immune system of fish, which might be effective to fight against infectious diseases.

\section{INTRODUCTION}

Aquaculture is a rapidly growing economic sector and a plethora of protein sources for human consumption (Hayatgheib et al., 2020). However, diseases cause a $50 \%$ production loss of this industry (Gabriel, 2019). Antibiotics and 'traditional' chemical therapeutics are administered to minimize the economic impact (Van Doan $\boldsymbol{e t}$ al., 2019; Lieke et al., 2020). However, the recurrent use of antibiotics in aquaculture system is not only hampering fish metabolism but also the environment and public health. This harmful effect allows horizontal gene transfer (HGT) of antibiotic resistance genes among diverse species with the collaboration of bacterial population, which leads to drugresistant pathogens (Watts et al., 2017). Vaccine is also used to treat the aquaculture diseases; however, it is relatively expensive and not effective for broad-spectrum use (Plant \& LaPatra, 2011). As a result, alternative sustainable strategies followed by substitutes for antibiotics, vaccines, or other chemical therapeutics, are highly needed that are characterized as immunostimulants by a broad-spectrum activity, which contribute to 
fish growth mechanism, and more precisely, cost-effective, eco-compatible best quality products from aquaculture indeed (Gabriel, 2019).

Over the past two decades, it has been a common trend of using plant-derived supplements rather than chemical residues in aquaculture because of many factors: low cost, ready availability, fewer side effects in fish health and sustainable practice for aquatic environments (Reverter et al., 2014; Van Hai, 2015; Gabriel, 2019). Plantenriched diets contain bioactive plant components such as phenols, alkaloids, flavonoids, tannins, terpenoids, saponins, glycosides, and essential oils that enhance fish growth, stimulate immune parameters, and increase disease resistance (Ghosh $\boldsymbol{e t}$ al., 2018). If proper administration occurs, medicinal plant can be an alternative means of synthetic drugs in aquaculture (Gabriel, 2019).

This review literature is carried out to focus on the beneficial actions of different medicinal plants in aquaculture. Most specifically, how medicinal plant products modulate the immune response of the fish body. In addition, the current study was organized to address several expressions of immune profiling and disease resistance genes.

\section{MEDICINAL PLANTS}

Traditionally, people were strongly dependant on medicinal plants to prevent and treat diseases (Tsabang et al., 2016). Several parts of medicinal plants like leaves, roots, rhizome, bark, bulbs, as well as seeds have been used as crude or extracting active compounds (Zhang et al., 2014). They are recorded for a diverse range of biological activities such as: modulation of the immune response, growth promotion, antioxidant enhancing, antistress, digestion-stimulating, and gastroprotective effects (Gabriel $\boldsymbol{e t}$ al., 2015). Moreover, drug resistance features was rarely diagnosed in fish body systems due to diversity in molecular extracts of medicinal plants, which are biodegradable compared to synthetic drugs (Reverter et al., 2014).

Application of medicinal plants in fish farming is mainly done by three established methods such as: oral administration, immersion or bathing, and injection (Revertet et al., 2014; Adel et al., 2015a). The oral application is the most common, economically suitable technique and less stressful for fish of any size, but least effective due to slow absorbance (Bulfon et al., 2015). Immersion is more useful for a small fish size population (weight $<15 \mathrm{gm}$ ) and could be expensive as it requires a large amount of solution preparation (Awad \& Awaad, 2017). The intraperitoneal injection method is very demanding and an effective way to provide an appropriate dose because an injection can act faster in the bloodstream and becomes functional. However, this method is difficult, labour-intensive, and not effective for fry and fingerlings (Alexander et al., 2010). Medicinal plants can be administrated singly or in combination for treating 
diseases in fish. Studies have shown that using extracts from a combination of medicinal plants provides better benefits to hosts (Jian \& Wu, 2004).

\section{THE USEFULNESS OF MEDICINAL PLANTS ON FISH HEALTH}

\subsection{As growth promoters}

Numerous studies confirmed that using medicinal plants as crudes, semi extracts or pure extracts stimulate appetite, promote weight gain (WG), and cause a specific growth rate (SGR) of fish species (Awad and Awaad, 2017). Generally, medicinal plants increase the digestive enzyme secretion, which leads to growth promotion and enhances an increase in the survival rate of fish (Van Hai, 2015). This suggestion was supported by Shalaby et al., (2006) who observed that crude extracts of Allium sativum increased WG, SGR, and feed intake of the Nile tilapia (Oreochromis niloticus) as well. Crude powder of caraway showed a significant impact as a growth promoter for the Nile tilapia (Ahmad and Abdel-Tawwab, 2011). Noticeably, extracts of Zingiber officinalis, Cynodon dactylon, Tridax procumbens, Piper longum, and Phyllanthus niruri increased the retention rate of Epinephalus tauvina (Punitha et al., 2008).

\subsection{As immunostimulants}

With the increasing demand for aquaculture in the fast-growing food sector, researchers have been heavily concerned to conduct studies on fish immune system (Secombes \& Wang, 2012). Fish fed medicinal plants containing bioactive compounds, that act as immunostimulants, boost the specific and the non-specific immune response (Ghosh et al., 2018). Since the immune system is a biological mechanism of protecting living organisms from pathogens, medicinal plants can boost up the immune responses of fish, which eventually increase their antipathogenic capability (Bulfon et al., 2015). Therefore, medicinal plants help to reduce the losses of fish production before the occurence of any disease (Awad \& Awaad, 2017). The application of medicinal plants were reported to improve the immunological parameters in many fishes, including lysozyme, phagocytic, respiratory burst, as well as complement activities, peroxidise, and anti-protease activities (Fig. 1). However, the activity of medical plants depends on dose, types of medicinal plants, as well as their active compounds and fish size.

\subsubsection{Lysozyme activity}

Lysozyme is an effective antimicrobial and antioxidant component that acts on the lytic action on peptidoglycan bacterial cell wall and control microbial growth (Liu et al., 2006). It plays an important role to develop non-specific or innate immunity of fish and shellfishes (Yang et al., 2015) since it stimulates and activates several complement components, neutrophils, and macrophages, which eventually cause phagocytosis of bacteria, parasite, and virus as an opsonin (Harikrishnan et al., 2011). Notably, lysozyme are shown at the early developmental stages of fish when the specific immunity is yet to develop and fight against microorganisms at the larval stage (Cecchini et al., 
2000). The upregulation of serum lysozyme indicates the advancement of different humoral immunity that can protect the fish body from any kind of infection (Harikrishnan et al., 2010). Several medicinal plants are reported to enhance lysozyme activity in fishes (Table 1).

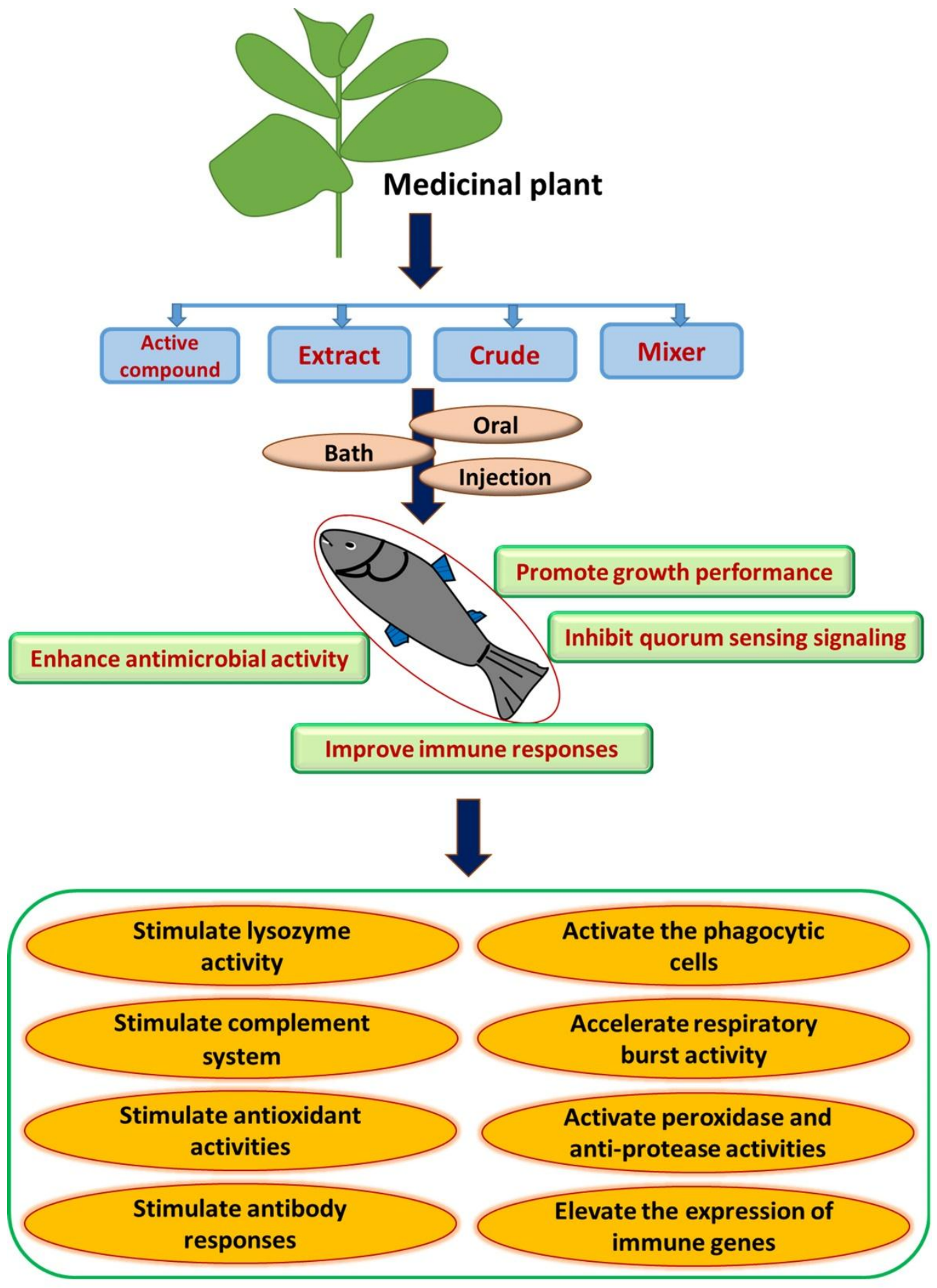

Fig. 1. Role of medicinal plants on immune status in fish. 


\subsubsection{Phagocytic and respiratory burst activity}

Phagocytosis constitutes a primitive defence against invading pathogens and involves internalization, killing, and digestion of invading pathogens (Harikrishnan $\boldsymbol{e t}$ al., 2011). Oxidative burst activity occurs due to the stimulated production of reactive oxygen from phagocytes, which are responsible for killing bacteria and other pathogens during phagocytosis (Carbone \& Faggio, 2016). It signals the active status of macrophage and neutrophil in the cell (Talpur, 2014). For vertebrates, phagocytosis is a fundamental defence mechanism, which is followed by the release of reactive oxygen species, such as superoxide anion $\left(\mathrm{O}_{2}-\right)$, hydrogen peroxide $\left(\mathrm{H}_{2} \mathrm{O}_{2}\right)$, and hydroxyl radical $(\mathrm{OH})$, all of which are highly antimicrobial; the antioxidant enzyme (superoxide dismutase, SOD, catalase, and glutathione peroxidase) can protect cells from damage (Messaoudi et al., 2009). The present study revealed that the phagocytic activity can be enhanced after dietary supplementation of several medicinal plants. Fish showed improved phagocytic and respiratory burst activity that lead to reduce susceptibility to pathogens due to various medicinal plants and their extract (Table 1).

\subsubsection{Peroxidase and anti-protease activity}

Peroxidases are the component of a large group enzyme that are clinically prominent and act as microbicidal agents, which not only utilize oxidative radicals to kill the pathogen but also used for ionic stability of immune cells. During the respiratory burst, it is mainly released by neutrophils. Anti-protease activities of serum are responsible for preventing proteolytic pathogen. Some medicinal plants were reported to elevate this activity in fish and showed higher survival against different pathogens (Table 1).

Table 1. List of medicinal plants and their extract used as immunostimulant.

\begin{tabular}{|c|c|c|c|c|}
\hline Medicinal plants & Fish species & Dose & Impacts & Reference \\
\hline $\begin{array}{l}\text { Ethanolic extracts of } \\
\text { propolis } \\
\text { Essential oil from } \\
\text { orange peel (Citrus } \\
\text { sinensis) }\end{array}$ & $\begin{array}{l}\text { Oreochromis } \\
\text { mossambicus }\end{array}$ & $\begin{array}{l}2,4 \mathrm{~g} \mathrm{~kg}^{-1} \\
1,3 \text {, and } 5 \mathrm{~g} \\
\mathrm{~kg}^{-1}\end{array}$ & $\begin{array}{l}\text { Increase lysozyme and } \\
\text { myeloperoxidase activity, total protein } \\
\text { and disease resistance against } \\
\text { Streptococcus iniae }\end{array}$ & $\begin{array}{l}\text { Acar (2018) } \\
\text { Acar et al. (2015) }\end{array}$ \\
\hline $\begin{array}{l}\text { Mucuna pruriens and } \\
\text { Cucurbita mixta seed } \\
\text { meal }\end{array}$ & & $\begin{array}{l}2,4 \text { and } 6 \mathrm{~g} \\
\mathrm{~kg}^{-1}\end{array}$ & $\begin{array}{l}\text { Enchance lysozyme, phagocytic, } \\
\text { respiratory burst, complement activity, } \\
\text { weight gain, feed efficiency ratio and } \\
\text { survival against Aeromonas } \\
\text { hydrophila }\end{array}$ & $\begin{array}{l}\text { Musthafa et al. } \\
(2017,2018)\end{array}$ \\
\hline $\begin{array}{l}\text { Cinnamon } \\
\text { nanoparticles (CNP) }\end{array}$ & O. niloticus & ${ }_{1}^{3} \mathrm{~g} \mathrm{CNP} \mathrm{kg}^{-}$ & $\begin{array}{l}\text { Enhance antioxidant and digestive } \\
\text { enzymes, activities, high survival } \\
\text { against } A \text {. hydrophila }\end{array}$ & $\begin{array}{l}\text { Abdel-Tawwab et } \\
\text { al. (2018a) }\end{array}$ \\
\hline $\begin{array}{l}\text { Astragalus } \\
\text { polysaccharides }\end{array}$ & & $\begin{array}{l}1500 \mathrm{mg} \mathrm{kg}^{-} \\
{ }^{1} \text { diet }\end{array}$ & $\begin{array}{l}\text { Improve growth performance, increase } \\
\text { phagocytic, respiratory burst, } \\
\text { lysozyme, bactericidal and amylase } \\
\text { activity }\end{array}$ & $\begin{array}{l}\text { Zahran et al. } \\
\text { (2014) }\end{array}$ \\
\hline
\end{tabular}


Propolis and Aloe

barbadensis (1:1)

Green tea and

Chinese herbal

mixtures

Peppermint (Metha piperita) plant extract

Ajwain

(Trachyspermum

ammi) and marjoram

(Origanum sp.)

extract

Lentinula edodes

mushroom extract

Ficuscarica

polysaccharide

Dill (Anethum

graveolens) and

garden cress

(Lepidium sativum)

Ginger (Zingiber

officinale) and Garlic

(Allium sativum)

Peppermint powder

Peppermint plant extract

Clove basil (Ocimum gratissimum) leaf extract

Plantagoasiatica and Houttuynia cordata

Pontogammarus maeoticus extract

Fenugreek

(Trigonella foenum graecum)
Onchorhynchu -s mykiss

$0.5,1.0$ and

$2 \%$

$0.5-2 \%$

$0,1,2,3 \%$

$1-2 \%$

$1-2 \%$

Ctenopharyng- $\quad 1.0 \%$

odon idella

Cyprinus

carpio

Lates

calcarifer

$5,10 \mathrm{~g} \mathrm{~kg}^{-1}$

Rutilus frisii

kutum and

Salmo trutta

Clarias

gariepinus

Rachycentron canadum

Rutilus

caspicus

Sparus aurata
5 and $10 \%$

$1 \%, 2 \%$, and $3 \%$

respiratory

only

$10,15 \mathrm{~g} \mathrm{~kg}^{-1}$

crease intestinal villi length, absorption area, reduce cholesterol and glucose level, increase protein, antioxidant and survival against Listeria monocytogenes

$10,20 \mathrm{~g} \mathrm{~kg}^{-1}$

$2 \%$

Induce phagocytosis, respiratory burst lysozyme activity.

Improve growth performance, feed intake salinity stress resistance, complement and lysozyme activity Increase haemolytic complement, peroxidase, antiprotease activity, enhance cellular and humoral immune parameters
Dotta et al. (2014)

Tang et al. (2014)

Adel et al. (2016)

Ali et al. (2017)

Baba et al. (2015)

Yang et al. (2015)

Bilen et al. (2018)

Talpur and

Ikhwanuddin, (2012, 2013)

Talpur (2014)

Adel et al. (2015a, 2015b)

Abdel-Tawwab et al. (2018b)

Wu et al. (2016)

Rufchaei et al. (2017)

Guardiola et al. (2018) 


\subsection{Enhance immune gene profile}

Immune related genes, such as interleukin 1 (IL-1 $\beta$ ), interleukin 8 (IL-8), tumour necrosis factor- $\alpha$ (TNF- $\alpha$ ), heat shock proteins (Hsp), $\beta$-defensins, transforming growth factor-beta (TGF- $\beta$ ) were reported as a defence mechanism and to have a growthpromoting effect. IL-1 $\beta$, IL-8, and TNF- $\alpha$ are early inflammatory cytokines secreted during inflammation (Zou \& Secombes, 2016). IL-1 $\beta$ and IL-8 induce host immune response to pathogenic infection and play a pivotal role in invading microbial community that damages tissues and organs causing autoimmune diseases (Engelsma et al., 2002), whereas TNF- $\alpha$ is important for rapid cellular proliferation, differentiation, and stimulation of other cytokines (Wei et al., 2009).

Several authors revealed that medicinal plants modulate the immune gene profile in various fish species. The up-regulation of IL- $1 \beta$ and TNF- $\alpha$ was found in grass carp (Ctenopharyngodon idella) when supplemented with Ficus carica polysaccharide at 0.5 and $1.0 \%$ of the basal diet for 21 days (Yang et al., 2015). Supplementation of dietary apple cider vinegar (ACV) in zebra fish (Danio rerio) diet reflected the induction of gene expression of lysozyme and interleukin 8 (IL-8), whereas no significant changes were found for IL-1 $\beta$ and TNF- $\alpha$ expression level (Ahmadifar et al., 2019).

On the other hand, olive leaf (Olea europea) showed dose and tissue dependent manner of immune gene expression in rainbow trout (O. mykiss). At low level of olive leaf extract, the expression of IL-1 $\beta$, IL-8, and TNF- $\alpha$ in the spleen tissue was elevated, but higher level showed down regulation of the gene expression (Baba et al., 2018). A significant increase in cytokine gene expression including IL-1 $\beta$, IL-8, IL-10, TGF- $\beta$, and IL-12p40 in the head kidney was observed when rainbow trout was fed with caper (Capparis spinosa), though the TNF- $\alpha$ was downregulated (Bilen et al., 2016). The intramuscular administration of flavonoids in Heliotropium huascoense showed induction of TNF- $\alpha$, IL-1, IFN- $\alpha$, IFN- $\gamma$, and TGF- $\beta 1$ in the head kidney of Atlantic salmon, whereas flavonoids from Heliotropium sinuatum decreased the transcriptional expression of TNF- $\alpha$, IL-1, and IL-12 (Valenzuela et al., 2018). Hence, the effect of medical plants on fish immunity varies with the fish species and their immune organ, type of medicinal plants, and their concentrations.

\subsection{Enhance antimicrobial activity}

The medicinal plant extracts consisting of antimicrobial properties can be applied for the treatment of certain diseases caused by specific pathogens, including bacteria, viruses, fungi, or parasites (Harikrishnan et al., 2009).

\subsubsection{Antiviral activity}

Lymphocystis disease virus (LDV), viral haemorrhagic septicaemia virus (VHSV), and aquabirnavirus (ABV) are the most frequent viruses that cause severe economic loss to the fish farmers (Harikrishnan et al., 2010). Solvent extracts of Punica granatum against lymphocystis disease virus (LDV) for eight weeks significantly 
increase relative percent survival (RPS) in olive flounder (Paralichthys olivaceus) (Harikrishnan et al., 2010). Cynodondactylon was used for the treatment of black tiger shrimp (Penaeus monodon) infected with white spot syndrome virus (WSSV), and resulted in neither fatality nor signs of infection compared to control groups, where $100 \%$ mortality was observed (Balasubramanian et al., 2008).

\subsubsection{Antibacterial activity}

Several authors displayed the antibacterial functionality of medicinal plants against both gram-positive and gram-negative bacteria (Van Hai, 2015). Cinnamon showed an antagonistic effect in the Nile tilapia (O. niloticus) against Aeromonas hydrophila (Ahmad et al., 2011). Extracts of Punica granatum was effective against methicillin-sensitive Staphylococcus aureus (MSSA), methicillin-resistant S. aureus (MRSA), Escherichia coli O157:H7, Salmonela typhi, and some streptococci strains (Rani et al., 2004; Braga et al., 2005).

\subsubsection{Antifungal/antiparasitic activity}

Prominent herbs also showed antifungal or anti parasitic effectiveness against certain fungal or parasitic strains in aquaculture. Ethanolic extracts of Piper guineese (fruits) and Xylopia aethiopica (seeds) showed antifungal activity against the fungus Candida albicans (Okeke et al., 2001). Datura metal Linn (Thorn -apple) displayed a prominent effect against fungal fish pathogens, being the most active for treating penicillium restrictum fungal infection (Madhuri et al., 2012).

\subsection{Alternative to antibiotics}

Previous studies proved that medicinal plants can be used as promising antibiotics for fish species by increasing immune status to resist diseases (Van Hai, 2015). Azadirachta indica stimulated the primary and secondary antibody responses in $O$. mossambicus, and could be alternative for antibiotics against the infection of Citrobacter freundii (Thanigaivel et al., 2015). Similarly, Ocimum sanctum accelerates antibody production and disease resistance in the Nile tilapia against A. hydrophila infection (Logambal et al., 2000). Sargassum duplicatum and Sargassum wightii could be used as a substitute for antibiotics to prevent white spot syndrome virus disease in black tiger prawns (Immanuel et al., 2010). For treating enteritis in grass carp, a combination of four herbs could be used as an alternative to antibiotics (Choi et al., 2014).

\subsection{As quorum sensing inhibitor}

Quorum sensing (QS) or Quorum signalling (QS) is the inter and intraspecific communication system of bacteria that allows bacterial adhesion and growth, virulence properties, antibiotic resistance, biofilm maturation, and so on (Defoirdt et al., 2008). There has been a growing interest to inhibit QS signalling due to the increasing rate of 
bacterial drug resistance (Defoirdt et al., 2008). A broad spectrum of secondary metabolites (flavonoids, phenols, phenolic acids, saponins, coumarins, tannins, quinones, terpenoids, alkaloids, and polyacetylenes) synthesized by medicinal plants, proved to have a significant effect on the QS system of Escherichia coli, Staphylococcus aureus, and Chromobacterium violaceum (Bouyahya et al., 2017). Moreover, the substance of essential oil produced by aromatic plants sustained an active effect against certain bacterial strains of Salmonella, Listeria, Pseudomonas, Staphylococcus, and Lactobacillus sp. Additionally, extract from the Terminalia bellerica plant hindered the QS communication system of $P$. aeruginosa (Ganesh \& Rai, 2018).

\section{FUTURE STUDIES}

Medicinal plants possess a complex chemical composition suitable for the treatment of multifactorial diseases, showing potential effects on growth and survival, making plants a suitable alternative to antibiotics (Srivastava et al., 2014). However, many antinutritional factors are also found in medicinal plants like tannin, phytic acid, trypsin inhibitor, lectins, saponins, alkaloids, and antigenic compounds (Mohanta, 2012). Sometimes the rate of development and feed efficiency in the fish body recorded a decrease due to anti-nutritional, which contain an inappropriate ratio of amino acid (Hansen \& Hemre, 2013). Therefore, research is necessary to minimize the side effects of antinutritional components and enrich the products for best use.

Several studies explained that the efficiency of different medicinal plants strongly depends on various fish species and additional factors like dosage, method of extraction and types of extracts, route of administration, and other physiological aspects (Harikrishnan et al., 2011). Therefore, more studies are required to optimize the dosage application to standardize medicinal plant applications for immune response. Moreover, the effects of medicinal plants on the different life stages of fishes (i.e. fry, fingerlings, juveniles, preadults, and adults) are detected except for infancy. Consequently, future studies are recommended for this aspect.

In conclusion, this review reveals the advantages of medicinal plants in aquaculture as immunostimulants and alternatives to antibiotics, or chemotherapeutic agents. For the sustainability of the growing fish industry, it is vital to find a more feasible and well-developed protocol for using medicinal plants in aquaculture. For the large-scale fish industries, commercially produced medicinal plants are highly recommended. 


\section{REFERENCES}

Abdel-Tawwab, M.; Samir, F.; Abd El-Naby, A.S. and Monier, M.N. (2018a). Antioxidative and immunostimulatory effect of dietary cinnamon nanoparticles on the performance of Nile tilapia, Oreochromis niloticus (L.) and its susceptibility to hypoxia stress and Aeromonas hydrophila infection. Fish. Shellfish. Immunol., 74: 19-25.

Abdel-Tawwab, M.; Adeshina, I.; Jenyo-Oni, A.; Ajani, E.K. and Emikpe, B.O. (2018b). Growth, physiological, antioxidants, and immune response of African catfish, Clarias gariepinus (B.), to dietary clove basil, Ocimum gratissimum, leaf extract and its susceptibility to Listeria monocytogenes infection. Fish. Shellfish. Immunol., 78: 346-354.

Acar, Ü. (2018). Effects of diet supplemented with ethanolic extract of propolis on growth performance, hematological and serum biochemical parameters and disease resistance of Mozambique tilapia (Oreochromis mossambicus) against Streptococcus iniae. Aquac., 495: 339-344.

Acar, Ü.; Kesbiç, O.S.; Yılmaz, S.; Gültepe, N. and Türker, A. (2015). Evaluation of the effects of essential oil extracted from sweet orange peel (Citrus sinensis) on growth rate of tilapia (Oreochromis mossambicus) and possible disease resistance against Streptococcus iniae. Aquac., 437: 282-286.

Adel, M.; Abedian Amiri, A.; Zorriehzahra, J.; Nematolahi, A. and Esteban, M.A. (2015a). Effects of dietary peppermint (Mentha piperita) on growth performance, chemical body composition and hematological and immune parameters of fry Caspian white fish (Rutilus frisii kutum). Fish. Shellfish. Immunol., 45: 841-847.

Adel, M.; Safari, R.; Pourgholam, R.; Zorriehzahra, J. and Esteban, M.Á. (2015b). Dietary peppermint (Mentha piperita) extracts promote growth performance and increase the main humoral immune parameters (both at mucosal and systemic level) of Caspian brown trout (Salmo trutta caspius Kessler, 1877). Fish. Shellfish. Immunol., 47: 623-629.

Adel, M.; Pourgholam, R.; Zorriehzahra, J. and Ghiasi, M. (2016). Hemato Immunological and biochemical parameters, skin antibacterial activity, and survival in rainbow trout (Oncorhynchus mykiss) following the diet supplemented with Mentha piperita against Yersinia ruckeri. Fish. Shellfish. Immunol., 55, 267273.

Ahmad, M.H.; El Mesallamy, A.M.D.; Samir, F. and Zahran, F. (2011). Effect of cinnamon (Cinnamomum zeylanicum) on growth performance, feed utilization, whole-body composition, and resistance to Aeromonas hydrophila in Nile Tilapia. J. Appl. Aquac., 23: 289-298.

Ahmad, M.H. and Abdel-Tawwab, M. (2011). The use of caraway seed meal as a feed additive in fish diets: growth performance, feed utilization, and whole-body 
composition of Nile tilapia, Oreochromis niloticus (L.) fingerlings. Aquac., 314(1-4): 110-114.

Ahmadifar, E.; Dawood, M.A.; Moghadam, M.S.; Sheikhzadeh, N.; Hoseinifar, S.H. and Musthafa, M.S. (2019). Modulation of immune parameters and antioxidant defence in zebrafish (Danio rerio) using dietary apple cider vinegar. Aquac., 513: 734412.

Alexander, C.P.; Kirubakaran, C.J.W. and Michael, R.D. (2010). Water soluble fraction of Tinospora cordifolia leaves enhanced the non-specific immune mechanisms and disease resistance in Oreochromis mossambicus. Fish. Shellfish. Immunol., 29(5): 765-772.

Ali, M.; Soltanian, S.; Akbary, P. and Gholamhosseini, A. (2017). Growth performance and lysozyme activity of rainbow trout fingerlings fed with vitamin E and selenium, marjoram (Origanum spp.), and ajwain (Trachyspermum ammi) extracts. J. Appl. Anim. Res., 46: 650-660.

Awad, E. and Awaad, A. (2017). Role of medicinal plants on growth performance and immune status in fish. Fish. Shellfish. Immunol., 67: 40-54.

Baba, E.; Acar, Ü.; Yılmaz, S.; Zemheri, F. and Ergün, S. (2018). Dietary olive leaf (Olea europea L.) extract alters some immune gene expression levels and disease resistance to Yersinia ruckeri infection in rainbow trout Oncorhynchus mykiss. Fish. Shellfish. Immunol., 79, 28-33.

Baba, E.; Uluköy, G. and Öntaş, C. (2015). Effects of feed supplemented with Lentinula edodes mushroom extract on the immune response of rainbow trout, Oncorhynchus mykiss, and disease resistance against Lactococcus garvieae. Aquac., 448, 476-482.

Balasubramanian, G.; Sarathi, M.; Venkatesan, C.; Thomas, J. and Hameed, A.S. (2008a). Oral administration of antiviral plant extract of Cynodon dactylon on a large scale production against white spot syndrome virus (WSSV) in Penaeus monodon. Aquac., 279: 2-5.

Bilen, S.; Altunoglu, Y.C.; Ulu, F. and Biswas, G. (2016). Innate immune and growth promoting responses to caper (Capparis spinosa) extract in rainbow trout (Oncorhynchus mykiss). Fish. Shellfish. Immunol., 57: 206-212.

Bilen, S.; Bulut, M. and Bilen, A.M. (2011). Immunostimulant effects of Cotinus coggyria on rainbow trout (Oncorhynchus mykiss). Fish. Shellfish. Immunol., 30, 451-455.

Bilen, S.; Özkan, O.; Alagöz, K. and Özdemir, K.Y. (2018). Effect of dill (Anethum graveolens) and garden cress (Lepidium sativum) dietary supplementation on growth performance, digestive enzyme activities and immune responses of juvenile common carp (Cyprinus carpio). Aquac., 495: 611-616. 
Bouyahya A.; Dakka N.; Et-Touys A.; Abrini J. and Bakri Y. (2017). Medicinal plant products targeting quorum sensing for combating bacterial infections. Asian Pac. J. Trop. Med., 10(8): 729-743.

Braga, L.C.; Leite, A.A.; Xavier, K.G.; Takahashi, J.A.; Bemquerer, M.P., Chartone-Souza, E. and Nascimento, A.M. (2005). Synergic interaction between pomegranate extract and antibiotics against Staphylococcus aureus. Can. J. Microbiol., 51(7): 541-547.

Bulfon, C.; Volpatti, D. and Galeotti, M. (2015). Current research on the use of plantderived products in farmed fish. Aquac. Res., 46: 513-551.

Carbone, D. and Faggio, C. (2016). Importance of prebiotics in aquaculture as immunostimulants. Effects on immune system of Sparus aurata and Dicentrarchus labrax. Fish. Shellfish. Immunol., 54: 172-178.

Cecchini, S.; Terova, G.; Caricato, G. and Saroglia, M. (2000). Lysozyme activity in embryos and larvae of Sea Bass (Dicentrarchus labrax L.), spawned by broodstock fed with Vitamin C enriched diets. Bull. Eur. Assoc. Fish. Pathol., 20: $120-124$.

Choi, W.M.; Mo, W.Y.; Wu, S.C.; Mak, N.K.; Bian, Z.X.; Nie, X.P. and Wong, M.H. (2014). Effects of traditional Chinese medicines (TCM) on the immune response of grass carp (Ctenopharyngodon idellus). Aquac Int., 22: 361-377.

Defoirdt, T.; Boon, N.; Sorgeloos, P.; Verstraete, W. and Bossier, P. (2008). Quorum sensing and quorum quenching in Vibrio harveyi: lessons learned from in vivo work. ISME J., 2: 19-26.

Dotta, G.; de Andrade, J.I.; Tavares Goncalves, E.L.; Brum, A.; Mattos, J.J.; Maraschin, M. and Martins, M.L. (2014). Leukocyte phagocytosis and lysozyme activity in Nile tilapia fed supplemented diet with natural extracts of propolis and Aloe barbadensis. Fish. Shellfish. Immunol., 39: 280-284.

Engelsma, M.Y.; Huising, M.O.; van Muiswinkel, W.B.; Flik, G.; Kwang, J.; Savelkoul, H.F. and Verburg-van Kemenade, B.L. (2002). Neuroendocrineimmune interactions in fish: a role for interleukin-1. Vet. Immunol. Immunopathol., 87: 467-479.

Gabriel, N.N.; Qiang, J.; Ma, X.Y.; He, J.; Xu, P. and Liu, K. (2015). Dietary Aloe vera improves plasma lipid profile, antioxidant, and hepatoprotective enzyme activities in GIFT-tilapia (Oreochromis niloticus) after Streptococcus iniae challenge. Fish Physiol. Biochem., 41: 1321-1332.

Gabriel, N.N. (2019). Review on the progress in the role of herbal extracts in tilapia culture. Cogent Food Agri., 5: 1619651.

Ganesh, P.S. and Rai, V.R. (2018). Attenuation of quorum-sensing-dependent virulence factors and biofilm formation by medicinal plants against antibiotic resistant Pseudomonas aeruginosa. J. Trad. Comp. Med., 8(1): 170-177. 
Ghosh, K., Ray, A.K. and Ringø, E. (2018). Applications of plant ingredients for tropical and subtropical freshwater finfish: possibilities and challenges. Rev. Aquac., 11: 793-815.

Guardiola, F.A.; Bahi, A. and Esteban, M.A. (2018). Effects of dietary administration of fenugreek seeds on metabolic parameters and immune status of gilthead seabream (Sparus aurata L.). Fish. Shellfish. Immunol., 74: 372-379.

Hansen, A.C. and Hemre, G.I. (2013) Effect of replacing fish meal and oil with plant resources in on-growing diets for Atlantic cod Gadus morhua L. Aquac. Nutri., 19: 641-650.

Harikrishnan R.; Balasundaram C.; Moon Y.G.; Kim M.C.; Kim J.S. and Heo M.S. (2009). Use of herbal concoction in the therapy of goldfish (Carassius auratus) infected with Aeromonas hydrophila. Bull. Vet. Inst.Pulawy., 53: 27-36.

Harikrishnan, R.; Heo, J.; Balasundaram, C.; Kim, M.C.; Kim, J.S.; Han, Y.J. and Heo, M.S. (2010). Effect of Punica granatum solvent extracts on immune system and disease resistance in Paralichthys olivaceus against lymphocystis disease virus (LDV). Fish Shellfish Immunol., 29(4): 668-673.

Harikrishnan, R.; Balasundaram, C. and Heo, M.S. (2011). Impact of plant products on innate and adaptive immune system of cultured finfish and shellfish. Aquac., 317(1-4): 1-15.

Hayatgheib, N.; Moreau, E.; Calvez, S.; Lepelletier, D. and Pouliquen, H. (2020). A review of functional feeds and the control of Aeromonas infections in freshwater fish. Aquac. Int., 28: 1083-1123.

Immanuel, G.; Sivagnanavelmurugan, M.; Balasubramanian, V. and Palavesam, A. (2010). Effect of hot water extracts of brown seaweeds Sargassum spp. on growth and resistance to white spot syndrome virus in shrimp Penaeus monodon postlarvae. Aquac. Res. 41: 545-553.

Jian, J. and Wu, Z. (2004). Influences of traditional Chinese medicine on non-specific immunity of Jian carp (Cyprinus carpio var. Jian). Fish. Shellfish. Immunol., 16: 185-191.

Lieke, T.; Meinelt, T.; Hoseinifar, S.H.; Pan, B.; Straus, D.L. and Steinberg, C.E. (2020). Sustainable aquaculture requires environmental- friendly treatment strategies for fish diseases. Rev. Aquac., 12: 943-965.

Liu, H.; Zheng, F.; Cao, Q.; Ren, B.; Zhu, L.; Striker, G. and Vlassara, H. (2006). Amelioration of oxidant stress by the defensin lysozyme. Am. J. Physiol. Endocrinol. Meta., 290: 824-832.

Logambal, S.M.; Venkatalakshmi, S. and Michael, R.D. (2000). Immunostimulatory effect of leaf extract of Ocimum sanctum Linn. in Oreochromis mossambicus (Peters). Hydrobiologia., 430: 113-120. 
Madhuri, S.; Mandloi, A.K.; Govind, P. and Sahni, Y.P. (2012). Antimicrobial activity of some medicinal plants against fish pathogens. Int. Res. J. Phar., 3(4): 28-30.

Messaoudi, I.; Barhoumi, S.; Saïd, K. and Kerken, A. (2009). Study on the sensitivity to cadmium of marine fish Salaria basilisca (Pisces: Blennidae). J. Environ. Sci., 21: $1620-1624$.

Mohanta, K.N. (2012) Plant feed resources of India. In: Sogbesan, O.A., Mohanta, K.N., Sahoo, P.K., Mitra, G. \& Jayasankar, P. (Eds.). Invited Papers on Application of Solid State Fermentation Technology in Aquaculture, Central Institute of Freshwater Aquaculture, Bhubaneswar, India, pp. 100-113.

Musthafa, M.S.; Asgari, S.M.; Kurian, A.; Elumalai, P.; Ali, A.RJ.; Paray, B.A. and Al-Sadoon, M.K. (2018). Protective efficacy of Mucuna pruriens (L.) seed meal enriched diet on growth performance, innate immunity, and disease resistance in Oreochromis mossambicus against Aeromonas hydrophila. Fish. Shellfish. Immunol., 75: 374-380.

Musthafa, M.S.; Jawahar Ali, A.R.; Arun Kumar, M.S.; Paray, B.A.; Al-Sadoon, M.K.; Balasundaram, C. and Harikrishnan, R. (2017). Effect of Cucurbita mixta (L.) seed meal enrichment diet on growth, immune response and disease resistance in Oreochromis mossambicus. Fish. Shellfish. Immunol., 68: 509-515.

Okeke, M.I.; Iroegbu, C.U.; Jideofor, C.O.; Okoli, A. and Esimone, C.O. (2001). Anti-microbial activity of ethanol extracts of two indigenous Nigerian spices. J. Herbs, Spices Med Plants., 8: 39-48.

Plant, K.P. and LaPatra, S.E. (2011). Advances in fish vaccine delivery. Dev. Com. Immunol., 35(12): 1256-1262.

Punitha, S.M.J.; Babu, M.M.; Sivaram, V.; Shankar, V.S.; Dhas, S.A.; Mahesh, T.C.; Immanuel, G. and Citarasu, T. (2008). Immunostimulating influence of herbal biomedicines on nonspecific immunity in Grouper Epinephelus tauvina juvenile against Vibrio harveyi infection. Aquac. Int., 16: 511-523.

Rani, P. and Khullar, N. (2004). Antimicrobial evaluation of some medicinal plants for their anti- enteric potential against multi- drug resistant Salmonella typhi. Phytother. Res., 18(8): 670-673.

Reverter, M.; Bontemps, N.; Lecchini, D.; Banaigs, B. and Sasal, P. (2014). Use of plant extracts in fish aquaculture as an alternative to chemotherapy: current status and future perspectives. Aquac., 433: 50- 61.

Rufchaei, R.; Hoseinifar, S.H.; Mirzajani, A. and Van Doan, H. (2017). Dietary administration of Pontogammarus maeoticus extract affects immune responses, stress resistance, feed intake and growth performance of caspian roach (Rutilus caspicus) fingerlings. Fish. Shellfish. Immunol., 63: 196-200.

Secombes, C. and Wang, T. (2012). The innate and adaptive immune system of fish. Infect. Dis. Aquac., 3-68. 
Shalaby, A.M.; Khattab, Y.A. and Abdel Rahman, A.M. (2006). Effects of Garlic (Allium sativum) and chloramphenicol on growth performance, physiological parameters and survival of Nile tilapia (Oreochromis niloticus). J. Venom. Anim. Toxins. Incl. Trop. Dis., 12(2): 172-201.

Srivastava, J.; Chandra, H.; Nautiyal, A.R. and Kalra, S.J.S. (2014) Antimicrobial resistance (AMR) and plant-derived antimicrobials (PDAms) as an alternative drug line to control infections. Biotech., 4: 451-460.

Talpur, A.D. (2014). Mentha piperita (Peppermint) as feed additive enhanced growth performance, survival, immune response and disease resistance of Asian seabass, Lates calcarifer (Bloch) against Vibrio harveyi infection. Aquac., 420-421: 71-78.

Talpur, A.D. and Ikhwanuddin, M. (2012). Dietary effects of garlic (Allium sativum) on haemato-immunological parameters, survival, growth, and disease resistance against Vibrio harveyi infection in Asian sea bass, Lates calcarifer (Bloch). Aquac., 364-365: 6-12.

Talpur, A.D. and Ikhwanuddin, M. (2013). Azadirachta indica (neem) leaf dietary effects on the immunity response and disease resistance of Asian seabass, Lates calcarifer challenged with Vibrio harveyi. Fish Shellfish Immunol., 34: 254-264.

Tang, J.; Cai, J.; Liu, R.; Wang, J.; Lu, Y.; Wu, Z. and Jian, J. (2014). Immunostimulatory effects of artificial feed supplemented with a Chinese herbal mixture on Oreochromis niloticus against Aeromonas hydrophila. Fish. Shellfish. Immunol., 39(2): 401-406.

Thanigaivel, S.; Vijayakumar, S.; Gopinath, S.; Mukherjee, A.; Chandrasekaran, N. and Thomas, J. (2015). In vivo and in vitro antimicrobial activity of Azadirachta indica (Lin) against Citrobacter freundii isolated from naturally infected Tilapia (Oreochromis mossambicus). Aquac., 437: 252-255.

Tsabang, N.; Ngah, N.; Estella, F.T. and Agbor, G.A. (2016). Herbal medicine and treatment of diabetes in Africa: Case study in Cameroon. Diab. Case Rep., 1(112): 2.

Valenzuela, B.; Rodriguez, F.E.; Modak, B. and Imarai, M. (2018). Alpinone exhibited immunomodulatory and antiviral activities in Atlantic salmon. Fish. Shellfish. Immunol., 74: 76-83.

Van Doan, H.; Hoseinifar, S.H.; Esteban, M.Á.; Dadar, M. and Thu, T.T.N. (2019). Mushrooms, seaweed, and their derivatives as functional feed additives for aquaculture: an updated view. Stud. Nat. Prod. Chem., 62: 41-90.

Van Hai, N. (2015). The use of medicinal plants as immunostimulants in aquaculture: A review. Aquac., 446: 88-96.

Watts, J.E.M.; Schreier, H.J.; Lanska, L. and Hale, M.S. (2017) The rising tide of antimicrobial resistance in aquaculture: sources, sinks and solutions. Mar. Drugs., 15(6):158. 
Wei, L.; Sun, B.; Chang, M.; Liu, Y. and Nie, P. (2009). Effects of cyanobacterial toxin microcystin-LR on the transcription levels of immune-related genes in grass carp Ctenopharyngodon idella. Environ. Biol. Fish., 85: 231.

Wu, C.C.; Liu, C.H.; Chang, Y.P. and Hsieh, S.L. (2010). Effects of hot-water extract of Toona sinensis on immune response and resistance to Aeromonas hydrophila in Oreochromis mossambicus. Fish. Shellfish. Immunol., 29: 258-263.

Wu, Y.S.; Chen, Y.Y.; Ueng, P.S. and Nan, F.H. (2016). Effects of medicinal herbs "Plantago asiatica", "Houttuynia cordata" and "Mentha haplocalyx" on nonspecific immune responses of cobia (Rachycentron canadum). Fish. Shellfish. Immunol., 58: 406-414.

Yang, X.; Guo, J.L.; Ye, J.Y.; Zhang, Y.X. and Wang, W. (2015). The effects of Ficus carica polysaccharide on immune response and expression of some immunerelated genes in grass carp, Ctenopharyngodon idella. Fish. Shellfish. Immunol., 42: 132-137.

Zahran, E.; Risha, E.; Abdelhamid, F.; Mahgoub, H.A. and Ibrahim, T. (2014). Effects of dietary Astragalus polysaccharides (APS) on growth performance, immunological parameters, digestive enzymes, and intestinal morphology of Nile tilapia (Oreochromis niloticus). Fish. Shellfish. Immunol., 38: 149-157.

Zhang, X.P.; Li, W.X.; Ai, T.S.; Zou, H.; Wu, S.G. and Wang, G.T. (2014). The efficacy of four common anthelmintic drugs and traditional Chinese medicinal plant extracts to control Dactylogyrus vastator (Monogenea). Aquac., 420: 302307.

Zou, J. and Secombes, C.J. (2016). The function of fish cytokines. Biol., 5: 23. 